\title{
BIOOKSIDASI: TEKNOLOGI ALTERNATIF PENGOLAHAN BIJIH EMAS REFRAKTORI
}

\author{
Biooxidation: An Alternative Technology for Refractory \\ Gold Ore Processing
}

\author{
SRI HANDAYANI dan SURATMAN \\ Puslitbang Teknologi Mineral dan Batubara \\ Jalan Jenderal Sudirman 623 Bandung 40211 \\ Telp. (022) 6030483, Fax. (022) 6003373 \\ e-mail: sri@tekmira.esdm.go.id
}

\begin{abstract}
ABSTRAK
Sekitar sepertiga produksi emas dunia berupa bijih emas refraktori. Sifat refraktori umumnya karena bijih emas berukuran halus dan terinklusi dalam mineral-mineral sulfida seperti arsenopirit dan pirit sehingga menyebabkan perolehan emas rendah (20-50\%) bila diolah dengan proses sianidasi langsung. Teknologi biooksidasi merupakan teknologi alternatif yang menarik sebagai prapengolahan bijih emas refraktori karena desain dan operasinya lebih sederhana, biaya kapital dan operasi rendah dan tidak menghasilkan bahan pencemar udara sehingga teknologi ini lebih ramah lingkungan. Indonesia mempunyai cadangan bijih emas refraktori yang cukup besar dan sangat berpotensi untuk diolah dengan teknologi biooksidasi karena teknologi ini telah terbukti layak secara teknis dan ekonomis, dan telah diaplikasikan selama 30 tahun terakhir di lebih dari 10 negara di seluruh dunia.Tulisan ini menyajikan informasi dan diskusi mengenai aplikasi teknologi biooksidasi dalam pengolahan bijih emas refraktori, landasan teori dan mekanisme reaksi, aplikasi komersial yang telah ada di dunia, hasil-hasil beberapa penelitian di Indonesia, aspek keekonomian, tantangan dan kendala serta potensi dan prospek aplikasinya di Indonesia. Hasil penelitian biooksidasi bijih emas refraktori Indonesia asal Kalimantan Timur, menunjukkan pada sianidasi langsung tanpa praolahan, perolehan emasnya hanya mencapai $38,7 \%$ dan setelah bijih mengalami pelindian bakteri selama 42 hari, ekstraksi emasnya meningkat menjadi 87,1 \%. Pada penelitian biooksidasi selanjutnya menggunakan kultur bakteri campuran Acidithiobacillus ferrooxsidan dan Acidithiobacillus thiooxidan, perolehan emasnya mencapai $98 \%$ dalam waktu proses yang lebih singkat selama 28 hari. Hasil-hasil tersebut memperkuat prospek penerapan teknologi biooksidasi secara komersial di Indonesia.
\end{abstract}

Kata kunci : biooksidasi, bijih emas refraktori, mikroba, teknologi alternatif

\begin{abstract}
About one third of the world's gold is in the form of refractory ores. The most common cause of refractoriness when the gold is finely disseminated in sulphide minerals such as arsenopyrite and pyrite, by physical lock-up in the sulfide grains. This resulted in poor gold recoveries (as low as 20 to 50\%) by direct cyanide leaching. Biooxidation is an attractive alternative option for pretreatment due to simplicity of design and operation, capital and operating cost are favourable, no airborne pollutants are produced, those making this technologgy more environmentally acceptable. Indonesia has a large deposit of refractory gold ores and potential to be processed using biooxidation technology because it has become an established commercial process over the past 30 years in more than 10 countries worldwide. This paper is essentially an overview of the pretreatment process for the refractory gold ores available in recent literatures and some results of experimental biooxidation studies which had been conducted in Indonesia. Also discuss an understanding of the chemical-biological reactions and mechanisms involved, its commercial application available, economic considerations, challenges and barriers and considerable potential application in Indonesia. Some biooxidation experimental results of Indonesia refractory gold ore originated from East Kalimanatan show that in direct sianidation, the gold recovery was only
\end{abstract}


$38.7 \%$, and after pretreatment by bacterial leaching, the gold extraction increased to $87.1 \%$. By using mixed bacterial culture of Acidithiobacillus ferrooxidans and A.thiooxidans, the gold recovery yielded 98\% in shorter process time of 28 days. Those results strongly support this biooxidation technology to be applied commercially in Indonesia.

Keywords : biooxidation, refractory gold ore, microbe, alternative technology

\section{PENDAHULUAN}

Logam emas merupakan komoditi penting bagi Indonesia karena merupakan sumber devisa dari sektor pertambangan. Proses pengolahan (ekstraksi) emas yang diterapkan secara komersial adalah dengan proses sianidasi. Proses sianidasi pada bijih emas oksida akan diperoleh ekstraksi minimal sekitar $97 \%$. Masalah dalam proses sianidasi timbul bila hal itu diterapkan untuk bijih emas yang bersifat refraktori, yaitu bila partikelpartikel logam emas berukuran sangat kecil (berdiameter 50 um) dan terinklusi dalam mineral-mineral sulfida seperti pirit, arsenopirit, kalkopirit. Dengan adanya pembungkus berupa mineral sulfida tersebut, proses sianidasi menjadi tidak efektif dan secara drastis menurunkan perolehan emas menjadi rendah, di bawah $50 \%$.

Untuk mengatasi masalah itu, perlu dilakukan proses praolahan untuk menghilangkan mineral sulfida dalam bijih sehingga emas yang terinklusi di dalamnya dapat terbebaskan. Salah satu proses praolahan konvensional yang telah dikenal adalah dengan pemanggangan (roasting) untuk mengubah sifat sulfidis menjadi oksidis. Proses tersebut mempunyai beberapa kelemahan, yaitu memerlukan konsumsi energi yang tinggi (prosesnya berlangsung pada suhu $600-800^{\circ} \mathrm{C}$ ), serta melepaskan gas pencemar $\mathrm{SO}_{2}$. Untuk menangkal pencemaran udara diperlukan instalasi khusus yang memerlukan biaya cukup mahal. Hal-hal tersebut menjadikan proses ini tidak ekonomis bila diterapkan pada bijih emas refraktori.

Dewasa ini telah dikembangkan metode praolahan bijih emas refraktori dengan menggunakan bakteri Acidithiobacillus ferrooxidans (dulu dikenal dengan Thiobacillus ferrooxidans), dan beberapa bakteri indigenos, yang disebut sebagai biooksidasi atau pelindian bakteri untuk melarutkan mineral-mineral sulfida pembungkus emas (Meybodi $d k k$., 2013; Shumilova, 2016). Reaksi biooksidasi tersebut dapat berlangsung pada suhu $2-40^{\circ} \mathrm{C}$, $\mathrm{pH}$ 1,0-6,0. Metode ini memberikan alternatif baru dalam praolahan bijih refraktori karena lebih ekonomis, konsumsi energinya rendah serta tidak menghasilkan gas pencemar (Karthikeyan, Rajasekar dan Balasubramanian, 2015; Bactech, 2017).

Tulisan ini menyajikan kajian aplikasi teknologi biooksidasi dalam pengolahan bijih emas refraktori, beberapa landasan teori dan mekanisme reaksinya, aplikasi komersialnya yang telah ada di dunia, tantangan dan kendalanya serta potensi aplikasinya di Indonesia.

\section{METODE}

Data yang digunakan dalam kajian ini adalah data sekunder dan primer. Data sekunder diperoleh dari berbagai instansi seperti Pusat Sumberdaya Geologi, Badan Geologi, Ditjen Minerba, Kementerian Perindustrian, Kementerian Perdagangan, serta sumber lain dari literatur dan jurnal ilmiah. Data primer berasal dari hasil-hasil penelitian yang telah dilakukan di Puslitbang Teknologi Mineral dan Batubara. Oleh karena itu, data yang digunakan dalam analisis bersifat kuantitatif dan kualitatif.

\section{TINJAUAN PENGOLAHAN BIJIH EMAS}

Emas merupakan logam mulia dengan harga tinggi. Emas terjadi secara alamiah di alam sebagai unsur. Dalam tabel periodik unsur, emas merupakan unsur dengan nomor atom 79 dengan lambang Au setelah perak dan tembaga dan termasuk golongan transisi golongan IB.

Emas yang terdapat di alam umumnya berupa butiran-butiran halus bersama tembaga, perak dan kadang bersama logam-logam golongan platina. Hal ini dimungkinkan karena kemiripan sifat dari unsur-unsur tersebut. Selain 
itu emas sering diperoleh dalam bentuk senyawaan sebagai mineral telurida, AuTe2 dan silvanit, AuAgTe4. Emas yang diperoleh dari alam biasanya dalam dua bentuk yaitu emas yang berupa butiran-butiran halus yang biasanya diperoleh dengan cara pendulangan dan emas yang diperoleh dari batuan-batuan yang mengandung emas yang disebut bijih emas. Batuan yang berkualitas tinggi adalah batuan yang mengandung sekitar 30 gram emas untuk setiap ton batuan emas, namun biasanya batuan yang ditambang sekurangkurangnya mengandung kadar emas di atas 8 gram per ton bijih emas (Anonymous, 2017).

Salah satu metode yang umum digunakan untuk mendapatkan logam emas adalah dengan proses sianidasi menggunakan $\mathrm{NaCN}$. Bahan yang akan diolah dapat berupa bijih emas yang telah digiling. Proses ini didasarkan pada sifat emas yang dapat larut dalam garam sianida dengan adanya oksigen. Larutan yang terbentuk kemudian ditambahkan serbuk seng untuk mengendapkan emas. Reaksinya mengikuti persamaan reaksi berikut (Flatman $d k k ., 2014)$ :

$\mathrm{Au}(\mathrm{s})+8 \mathrm{NaCN}(\mathrm{aq})+\mathrm{O}_{2}(\mathrm{~g})+2 \mathrm{H}_{2} \mathrm{O}(\mathrm{l}) \rightarrow$ $4 \mathrm{NaAu}(\mathrm{CN})_{2}(\mathrm{aq})+4 \mathrm{NaOH}(\mathrm{aq})$

$2 \mathrm{NaAu}(\mathrm{CN})_{2}(\mathrm{aq})+\mathrm{Zn}(\mathrm{s}) \rightarrow 2 \mathrm{NaCN}(\mathrm{aq})+$ $\mathrm{Zn}(\mathrm{CN})_{2}(\mathrm{aq})+2 \mathrm{Au}(\mathrm{s})$

Proses berlangsung pada $\mathrm{pH} 10$ selama $12-24$ jam dengan perolehan di atas 95\%.

Bila partikel logam emas berukuran kecil dengan diameter $<-50 \mu m$, akan bersifat refraktori karena terbungkus oleh mineralmineral arsenopirit, pirit, pirohit, kalkopirit atau silika. Diketahui, sekitar 15-30\% bijih emas termasuk bersifat refraktori (Goodbody, 2012). Bungkus mineral itu menghambat proses sianidasi yang merupakan metode umum untuk memperoleh logam emas, sehingga menjadikannya tidak efektif, dan perolehan emas bisa turun hingga 20\% saja.Bungkus mineral menjadi penghalang fisik antara logam emas dan larutan sodium sianida yang bersama-sama dengan oksigen terlarut sebagai oksidan pada kondisi normal bisa melarutkan logam emas dan perak dengan perolehan yang efisien.Karena itu bijih emas refraktori secara umum didefinisikan sebagai bijih emas yang tidak memberi perolehan secara ekonomis (dengan perolehan di bawah $80 \%$ ) bila diolah dengan metode sianidasi konvensional ketika bijih telah digerus sampai 53-75 mikron (Goodbody, 2012).

Dalam 20-30 tahun terakhir perolehan emas dari bijih refraktori makin mendapat perhatian karena banyaknya bijih yang tidak merespon secara memadai terhadap proses sianidasi langsung. Emas yang terkunci dalam mineral sulfida refraktori biasanya terbentuk dalam ikatan kimia sebagai logam emas berukuran mikro atau nano. Penyebab lain dari rendahnya perolehan melalui sianidasi konvensional adalah (Winarko $d k k$., 2015):

1. Rendahnya tingkat kelarutan emas karena adanya material karbonan (carbonaceous material),

2. Adanya mineral-mineral lain yang bereaksi dengan sianida

3. Adanya mineral-mineral timbal, tembaga atau antimoni

4. Terjadinya gangguan dan pasifasi dari produk-produk dekomposisi pirit dan mineral-mineral lain.

Pengetahuan mengenai mineralogi bijih merupakan titik awal yang sangat penting untuk menentukan alur proses pengolahan bijih emas refraktori. Karena sifat refraktori tersebut, bijih ini memerlukan perlakuan pendahuluan secara fisik atau kimia untuk mencapai tingkat perolehan emas yang memadai sebelum proses sianidasi. Berdasarkan mineralogi proses, kini telah terdapat beberapa proses yang telah dikembangkan dan sukses secara ekonomi selama beberapa tahun untuk mengolah bijih emas refraktori. Beberapa proses tersebut, di antaranya adalah sebagai berikut (Aazami $d k k ., 2013$; Engineers, 2017):

1. Pemanggangan (roasting)

2. Oksidasi bertekanan tinggi (pressure oxidation)

3. Oksidasi bakteri (biooksidasi)

Proses oksidasi bertekanan tinggi dan biooksidasi merupakan proses hidrometalurgi dan cenderung lebih diminati dibandingkan proses pemanggangan (pirometalurgi).

\section{Pemanggangan}

Tujuan pemanggangan bijih emas refraktori adalah untuk membebaskan logam emas. 
Kandungan sulfur dalam mineral dioksidasi menjadi gas sulfur dioksida. Kandungan arsenik dioksidasi menjadi oksida arsenik $\mathrm{As}_{2} \mathrm{O}_{3}$, dan kandungan besi dioksidasi menjadi oksida besi (III) $\mathrm{Fe}_{2} \mathrm{O}_{3}$. Dalam kondisi gas, $\mathrm{As}_{2} \mathrm{O}_{3}$ mengandung molekul-molekul $\mathrm{As}_{4} \mathrm{O}_{6}$. Penanggulangan $\mathrm{As}_{2} \mathrm{O}_{3}$ bagi perlindungan lingkungan menyebabkan meningkatnya biaya proses. Pencegahan polusi udara dari sulfur dioksida yang bisa menyebabkan hujan asam juga merupakan kelemahan utama dari proses pemanggangan. Di samping itu, metode pemanggangan bisa tidak efisien bila ada bungkus mineral silikat.

\section{Oksidasi Bertekanan Tinggi}

Metode oksidasi mineral secara kimia yang telah terbukti dalam skala komersial adalah oksidasi bertekanan tinggi (20 atm), berasal dari suplai oksigen cair yang pada temperatur tinggi $\left(200^{\circ} \mathrm{C}\right)$ bisa menyebabkan terjadinya oksidasi mineral. Dalam hal ini, produk larutannya adalah asam sulfat, asam arsenik (IV) $\mathrm{H}_{3} \mathrm{AsO}_{4}$ dan ion feri. Proses ini tidak menghasilkan polutan udara namun demikian, proses oksidasi bertekanan tinggi memerlukan desain dan material pabrik dengan standar kualitas yang tinggi, yang bila tidak cermat bisa terjadi kegagalan dalam pompa, valve,impeler, pipa, gasket serta penebalan lapisan dinding autoklaf.

\section{Oksidasi Bakteri (Biooksidasi)}

Proses biooksidasi menggunakan bakteri untuk mengkatalisis reaksi. Agen pengoksidasi adalah oksigen bertekanan kamar dan persamaan reaksinya identik dengan oksidasi bertekanan tinggi. Pada oksidasi arsenopirit :

$2 \mathrm{FeAsS}+5 \mathrm{O}_{2} \rightarrow \mathrm{Fe}_{2} \mathrm{O}_{3}+\mathrm{As}_{2} \mathrm{O}_{3}+2 \mathrm{SO}_{2} \ldots . .$. (a) $2 \mathrm{FeAsS}+7 \mathrm{O}_{2}+4 \mathrm{H}^{+}+2 \mathrm{H}_{2} \mathrm{O} \rightarrow 2 \mathrm{Fe}^{3+}+$ $2 \mathrm{H}_{3} \mathrm{AsO}_{4}+2 \mathrm{HSO}^{4-}$

Reaksi (a) terjadi pada suhu $600-800^{\circ} \mathrm{C}$ dan berlangsung cepat sekitar 8 jam. Reaksi (b) terjadi pada suhu $200^{\circ} \mathrm{C}$ dengan tekanan 20 atm, berlangsung selama 2-4 jam (oksidasi bertekanan tinggi), sedangkan pada biooksidasi prosesnya berlangsung pada suhu $30-55^{\circ} \mathrm{C}$, tekanan kamar, berlangsung selama 4-6 hari. Katalis biasanya beroperasi pada konsentrasi rendah, dan ini pula yang terjadi pada oksidasi bakteri. Populasi bakteri adalah sekitar $10^{13} \mathrm{sel}$ per liter, ekivalen dengan $1,7 \times 10^{11} \mathrm{M}$ dalam sel. Konsentrasi katalis yang sedemikian adalah sangat rendah sebagai material katalis.

Input proses biooksidasi terutama tergantung kepada jenis mikroorganisme yang digunakan yang mampu melarutkan mineral sulfida. Pengkondisian yang penting setelah menentukan jenis bakteri adalah:

- Bijih emas atau konsentrat untuk menyediakan energi bagi bakteri pelaku proses

- Kondisi pengudaraan (aerob atau anaerob) tergantung jenis bakteri yang digunakan

- Ketersediaan karbon dioksida karena bakteri memerlukannya sebagai makro nutrisi (karbon) untuk membangun massa sel

- Ketersediaan nitrogen, fosfor, potasium, magnesium dan nutrisi untuk proses biooksidasi

- Pengatur $\mathrm{pH}$ yang umumnya memerlukan kondisi sangat asam.

\section{MEKANISME REAKSI BIOOKSIDASI}

Mekanisme oksidasi mineral yang dikatalisis oleh bakteri telah dibahas secara luas, diantaranya oleh Taylor (2013), Rawlings dan Johnson (2007). Dalam proses biooksidasi mineral sulfida, reaksi pelarutan logam dapat dituliskan sebagai berikut:

$\mathrm{MS}+2 \mathrm{O}_{2} \rightarrow \mathrm{MSO}_{4}$

$M$ adalah logam bervalensi dua. Bila ion feri ada,reaksi tambahan berikut ini akan terjadi :

$\mathrm{MS}+2 \mathrm{Fe}^{3+} \rightarrow \mathrm{M}^{2+}+\mathrm{S}+2 \mathrm{Fe}^{2+}$

Mikroorganisme berperan dalam meningkatkan regenerasi ion feri dalam larutan dengan mengoksidasi ion fero sebagai berikut:

$2 \mathrm{Fe}^{2+}+1 / 2 \mathrm{O}_{2}+2 \mathrm{H}^{+} \rightarrow 2 \mathrm{Fe}^{3+}+\mathrm{H}_{2} \mathrm{O}$

Teknologi biooksidasi membebaskan emas yang terjebak dalam mineral sulfida yang ada dalam bentuk bijih emas refraktori, sehingga memungkinkan untuk memperoleh emas tersebut melalui proses sianidasi konvensional. Mekanisme biooksidasi mineral sulfida (dalam hal ini pirit) dapat dilihat secara skematik dalam Gambar 1. Biooksidasi arsenopirit dapat dituliskan dalam reaksi sebagai berikut : 
$4 \mathrm{FeAsS}+11 \mathrm{O}_{2}+6 \mathrm{H}_{2} \mathrm{O} \rightarrow 4 \mathrm{FeSO}_{4}+4 \mathrm{H}_{3} \mathrm{AsO}_{3}$ $\mathrm{H}_{3} \mathrm{AsO}_{3}+2 \mathrm{Fe}^{3+}+\mathrm{H} \rightarrow \mathrm{H}_{3} \mathrm{AsO}_{4}+2 \mathrm{Fe}^{2+}+2 \mathrm{H}^{+}$ $2 \mathrm{FeAsS}+7 \mathrm{O}_{2}+2 \mathrm{H}_{2} \mathrm{O}+4 \mathrm{H}^{+} \rightarrow 2 \mathrm{Fe}^{3+}+$ $2 \mathrm{H}_{3} \mathrm{AsO}_{4}+2 \mathrm{HSO}_{4}$

Dan oksidasi pirit adalah sebagai berikut:

$2 \mathrm{FeS}_{2}+7 \mathrm{O}_{2}+2 \mathrm{H}_{2} \mathrm{O} \rightarrow 2 \mathrm{FeSO}_{4}+2 \mathrm{H}_{2} \mathrm{SO}_{4}$

$4 \mathrm{FeSO}_{4}+\mathrm{O}_{2}+2 \mathrm{H}_{2} \mathrm{SO}_{4} \rightarrow 2 \mathrm{Fe}_{2}\left(\mathrm{SO}_{4}\right)_{3}+2 \mathrm{H}_{2} \mathrm{O}$

$\mathrm{FeS}_{2}+2 \mathrm{Fe}^{3+} \rightarrow 3 \mathrm{Fe}^{2+}+2 \mathrm{~S}$

$2 \mathrm{~S}+3 \mathrm{O}_{2}+2 \mathrm{H}_{2} \mathrm{O} \rightarrow 2 \mathrm{H}_{2} \mathrm{SO}_{4}$

$4 \mathrm{FeS}_{2}+15 \mathrm{O}_{2}+2 \mathrm{H}_{2} \mathrm{O}+4 \mathrm{H}^{+} \rightarrow 4 \mathrm{Fe}^{3+}+8 \mathrm{HSO}_{4}^{-}$

\section{Bakteri yang Berperan dalam Proses Biooksidasi}

Peran utama mikroorganisme dalam proses biooksidasi adalah mengkatalisis regenerasi ion feri dan proton yang bisa diperoleh dengan oksidasi ion fero dan sulfur. Mikroorganisme ini umumnya tumbuh dalam lingkungan yang aerob, anorganik dan ber-pH rendah. Derajat $\mathrm{pH}$ dalam tangki ataupun timbunan heapleaching bervariasi, tetapi umumnya sangat asam berkisar antara 1,0 hingga 2,0. Mikroorganisme yang paling penting adalah yang bersifat autotrof dan menggunakan karbondioksida sebagai sumber karbon. Walaupun sumber energi bervariasi tergantung jenis mineralnya, mikroorganisme ini tumbuh dengan mengoksidasi ion fero, atau ion sulfur, atau keduanya (Rawlings dan Johnson, 2007; Schippers $d k k .$, 2013; Watling, 2016).

Bakteri yang mampu mengkatalisis reaksi oksidasi mineral termasuk ke dalam kelompok bakteri kemolitoautotrof. Bakteri ini mempunyai kapasitas untuk memperoleh energi dari oksidasi material anorganik seperti mineral. Bakteri autotrof adalah bakteri yang bisa menggunakan karbondioksida sebagai satu-satunya sumber karbon. Di samping itu, bakteri juga diklasifikasikan berdasarkan kisaran suhu operasi yang paling efisien (optimal), yaitu bakteri mesofil (temperatur optimal $\left.20-40^{\circ} \mathrm{C}\right)$, termofil moderat $\left(40-55^{\circ} \mathrm{C}\right)$ dan termofil ekstrim (di atas $55^{\circ} \mathrm{C}$ ). Morfologi bakteri-bakteri tersebut dapat dilihat pada Gambar 2. Saat ini setidaknya telah diketahui 5 jenis mesofil yang cocok untuk oksidasi mineral sulfidis, yaitu Acidithiobacillus ferrooxidans, A. Thiooxidans dan A. caldus, serta Leptospirillum ferrooxidans dan $L$. ferriphilum. Bakteri termofil moderat yang telah dikenal sejauh ini hanya Sulfobacillus thermosulfidooxidans, dan Ferroplasma sp. yang termasuk ke dalam kelompok kemolitotrof fakultatif. Adapun bakteri yang termasuk termofil ekstrim adalah genus Sulfolobus, Metallosphaera dan Acidianus yang juga merupakan bakteri fakultatif kemolititrof, contohnya Acidianus brierleyi. Di dalam proses biooksidasi secara heapleaching di Newmont dengan menggunakan mikroorganisme indigenous, ditemukan 8 jenis mikroba sekaligus yang merupakan bakteri mesofilik dan termofil moderat, yaitu : Acidithiobacillus ferrooxidans, Leptospirillum ferriphilum, Ferroplasma acidophilium, Acidithiobacillus caldus, Sulfobacillus benefaciens, Sulfolobus acidophilus, Sulfolobus thermosulfidooxidans dan Sulfobacillus sp. (Brierley, 2008). Morfologi salah satu strain Acidithiobacillus ferrooxidans ATCC 53993 yang dilihat melalui SEM dapat dilihat pada Gambar 3.

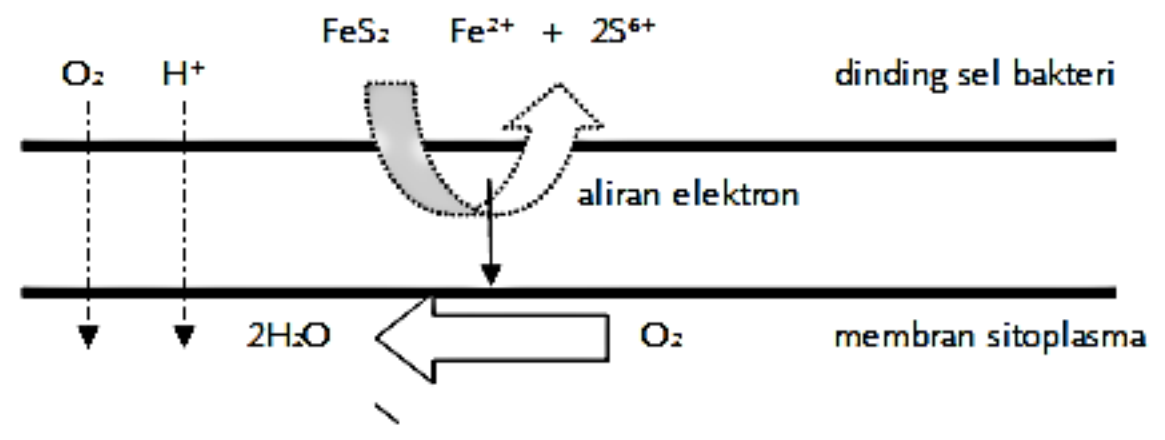

Gambar 1. Skema mekanisme biooksidasi pirit (modifikasi dari Rohwerder $d k k .$, 2003) 


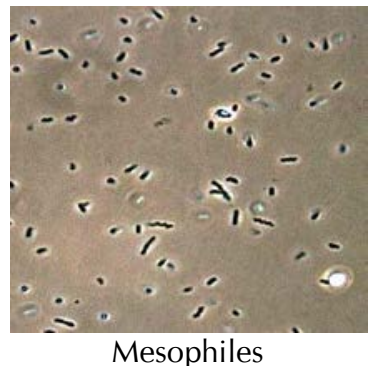

Mesophiles

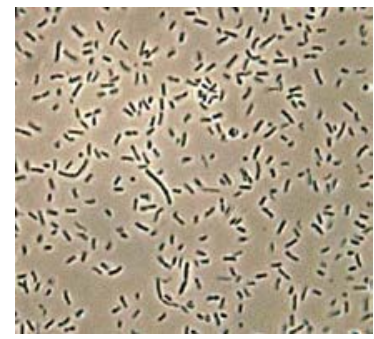

Moderate thermophiles

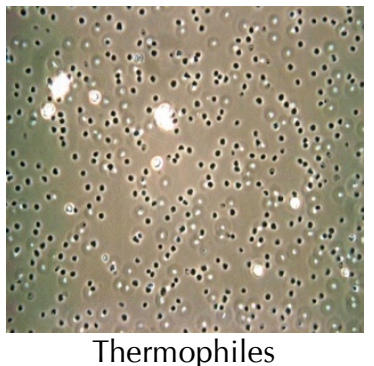

Thermophiles

Gambar 2. Mikroorganisme mesofil, termofil moderat dan termofil

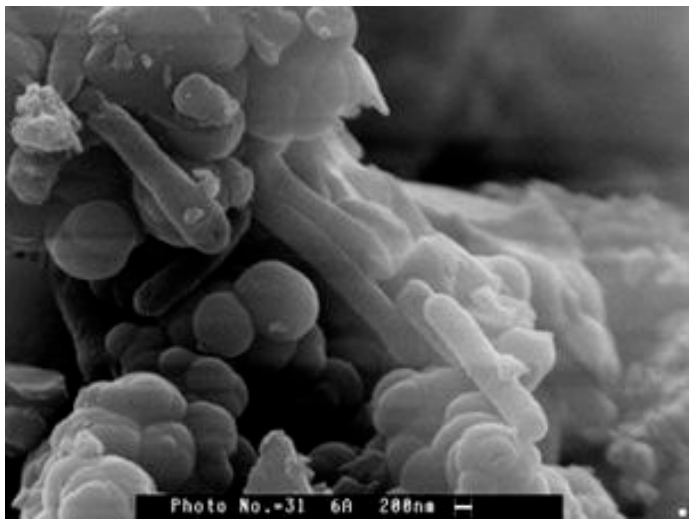

Gambar 3. Acidithiobacillus ferrooxidans ATCC 53993 (Anonymous, 2008)

Semua bakteri kemolitotrof dianggap sebagai bakteri obligat aerob, yaitu membutuhkan oksigen sebagai akseptor elektron atau agen pengoksidasi. Terdapat beberapa bukti bahwa sebagian bakteri kemolitoautotrof, pada kondisi tertentu, menjadi fakultatif aerobik ketika bakteri itu mendapatkan energi dengan menggunakan ion feri sebagai oksidan. Selain oksigen dan mineral sulfida, bakteri itu juga memerlukan larutan nutrisi yang mengandung ion-ion amonium, magnesium, kalsium, potasium, klorida, sulfat, nitrat dan fosfat. Unsur-unsur seperti seng dan mangan biasanya sudah terdapat mencukupi dalam mineral sehingga tidak perlu ditambahkan ke dalam sistem proses reaksi. Dengan demikian bakteri memerlukan sumber-sumber nutrisi tersebut di samping oksigen dan karbondioksida agar dapat melakukan reaksi katalisis oksidasi mineral.

Kultur bakteri yang digunakan dalam proses pembebasan emas dari mineral sulfida umumnya merupakan kultur campuran dari berbagai jenis bakteri yang telah dioptimalisasi sehingga menampilkan interaksi sinergis, meningkatkan pertumbuhan bakteri serta kinetika reaksi oksidasi bakteri
(Tanaka $d k k_{.,}$2015; Leng $d k k_{.,}$2016; Wang $d k k ., 2016)$. Sifat menonjol lain yang dimiliki adalah ketahanannya terhadap kandungan logam-logam yang sangat tinggi (metals resistance) (Martínez-Bussenius, Navarro dan Jerez, 2017).

\section{APLIKASI TEKNOLOGI BIOOKSIDASI SECARA KOMERSIAL}

Mekanisme reaksi secara kimia dan biokimia dari proses biooksidasi bijih sulfida telah diteliti dan dikembangkan secara ekstensif. Teknologi biooksidasi bijih sulfida telah diterapkan oleh industri pertambangan dan pengolahan emas secara komersial. Biooksidasi emas yang terjebak dalam bijih pirit/arsenopirit di antaranya telah dilakukan di Fairview Mine di Afrika Selatan, Sao Bento Mine di Brazil dan di Ashton Mining Harbour Lights Mine di Australia. Proses biooksidasi bijih refraktori emas terbesar sejauh ini adalah di Kokpatas, Uzbekistan yang mengolah 2.139 ton konsentrat per hari.

Secara keseluruhan, telah ada lebih dari 20 pabrik biooksidasi prapengolahan konsentrat emas refrakrori sulfidis seperti disajikan pada Tabel 1 (Brierley, 2010; van Niekerk, van den Heuvel dan van Buuren, 2014; Roberto, 2017). Pabrik-pabrik itu menggunakan tangki aerasi berpengaduk untuk mengoksidasi mineral pirit dan arsenopirit yang mengunci emas di dalam mineral tersebut. Pabrik Youanmi menggunakan teknologi BacTech Australia yang memanfaatkan kultur bakteri termofilik moderat, Sulfobacillus thermosulfidooxidans. Proses biooksidasi terjadi pada suhu $45-55^{\circ} \mathrm{C}$. Adapun pabrik lainnya menggunakan proses BIOX yang memanfaatkan kultur campuran Thiobacillus dan Leptospirillum pada suhu $40-45^{\circ} \mathrm{C}$. 
Pabrik biooksidasi di tambang Beaconsfield menggunakan kombinasi teknologi BacTech dan Mintek, beroperasi di Tasmania, Australia. Biooksidasi sebagai prapengolahan dalam tangki reaktor beroperasi secara komersial hanya untuk konsentrat flotasi bernilai tinggi. Adapun biooksidasi untuk prapengolahan bernilai rendah dilakukan secara pelindian onggok seperti yang telah dilakukan oleh Newmont Gold Mine. Bijih digerus sampai berukuran $12.7 \mathrm{~mm}$; timbunan bijih mempunyai ventilasi udara dan praolahan ini berlangsung selama 100 hingga 270 hari. Bijih yang telah teroksidasi kemudian dipindahkan, dinetralisasi dan dilindi lebih lanjut dengan sianida. Perolehan emas berkisar antara $60-80 \%$ tergantung sifat mineralogi dan ukuran partikel bijih. Biooksidasi sebagai praolahan secara pelindian onggok ini bila diterapkan pada bijih berkadar emas rendah, biayanya tidak ekonomis bila dibuat konsentrat, mineraloginya bersifat refraktori sulfidis yang tidak bisa dibuat konsentrat atau proyeknya terlalu kecil untuk dapat mendukung proses dengan modal yang besar.

\section{Biooksidasi Konsentrat}

Biooksidasi berlangsung dalam tangki berpengaduk (Gambar 4). Oksidasi bakterial terhadap sluri mineral yang telah digerus dapat dilakukan dalam tangki berpengaduk dan diberi aerasi bila nilai logam mencukupi untuk biaya pengadaan instalasi peralatan dan operasionalnya. Tangki reaksi bisa berupa tangki berpengaduk mekanik dengan memasukkan oksigen ke dalam sluri atau menggunakan reaktor Pachucha berpengaduk udara, yaitu disemburkan udara yang menyediakan oksigen sekaligus mengaduk sluri. Namun aplikasi Pachucha lebih terbatas karena dibatasi oleh ukuran tangki dan biaya yang relatif lebih tinggi.

Kinetika oksidasi dalam tangki berpengaduk lebih cepat dibandingkan dengan sistem in situ atau heapleaching. Sistem konsentrat memerlukan tangki lebih kecil sehingga lebih murah namun memerlukan sirkuit konsentrasi dan membutuhkan suhu proses yang lebih rendah.

Tabel 1. Pabrik biooksidasi komersial mengolah konsentrat flotasi

\begin{tabular}{|c|c|c|c|c|}
\hline Lokasi Pabrik & $\begin{array}{c}\text { Kapasitas } \\
\text { (t/hari) }\end{array}$ & $\begin{array}{c}\text { Kadar S } \\
(\%)\end{array}$ & Ukuran reaktor $\left(\mathrm{m}^{3}\right)$ & Tahun beroperasi \\
\hline Fairview, Afrika Selatan & 62 & 14,3 & 340 & 1986,1991- sekarang \\
\hline Carlin, Nevada & & & & $1988-2009$ \\
\hline Sao Bento, Brasil & 150 & 19 & 550 & 1990 - sekarang \\
\hline Harbour Lights, Australia & 40 & 18 & 160 & $1992-1994$ \\
\hline Wiluna, Australia & 158 & 24 & 480 & 1993 - sekarang \\
\hline Ashanti, Ghana & 960 & 9,1 & 900 & 1994 - sekarang \\
\hline Coricancha, Peru & 60 & 30 & 262 & 1998-sekarang \\
\hline Fosterville, Australia & 211 & 21 & 900 & 2005-sekarang \\
\hline Suzdal, Kazakhstan & 520 & 12 & 650 & 2005-sekarang \\
\hline Bogoso, Ghana & 820 & 16 & 1500 & 2007-sekarang \\
\hline Jinfeng, Cina & 790 & 9,4 & 1000 & 2007-sekarang \\
\hline Kokpatas, Uzbekistan & 2139 & 20 & 900 & 2009-sekarang \\
\hline Agnes, Afrika Selatan & 20 & 30 & 66 & 2010-sekarang \\
\hline Suzdal, Kazakhstan & 196 & & & 2005-sekarang \\
\hline Bogoso, Ghana & 750 & & & 2006-sekarang \\
\hline Kokpatas, Uzbekistan & 1069 & & & 2008-sekarang \\
\hline Youanmi, Australia & 120 & & & 1994-1998 \\
\hline Sansu, Ghana & 960 & & & 1994-sekarang \\
\hline Obuasi, Ghana & 1050 & & 895 & 1994-sekarang \\
\hline Beaconsfield, Australia & 70 & & 370 & 2000-sekarang \\
\hline Tamboraque, Peru & 60 & & & 1999 - sekarang \\
\hline Jinfeng, Cina & 790 & & & 2006-sekarang \\
\hline Yantai, Cina & 60 & & & 2000 - sekarang \\
\hline Laizhou, Cina & 100 & & & 2001 - sekarang \\
\hline
\end{tabular}




\section{Biooksidasi Pelindian Onggok (Heapleaching)}

Pelindian onggok dibentuk dengan cara menumpukkan bijih kadar rendah yang telah digerus di atas bantalan kedap cairan yang mempunyai kemiringan tertentu yang memungkinkan larutan untuk mengalir berdasarkan gaya gravitasi menuju saluran penampung (Gambar 5.) Oksigen dapat ditambahkan ke dalam sistem untuk meningkatkan laju oksidasi dengan mengalirkan udara bertekanan rendah ke dasar timbunan melalui perpipaan. Bisa juga dilakukan prainokulasi untuk membantu meningkatkan permeabilitas dan laju oksidasi. Timbunan bijih diberi irigasi dengan larutan ber-pH rendah mengandung nutrisi untuk membantu pertumbuhan bakteri. Residu hasil biooksidasi dipindahkan untuk diproses lebih lanjut dengan sianidasi. Sistem ini mempunyai biaya kapital dan operasi yang jauh lebih rendah, namun kelemahan utamanya adalah laju oksidasi yang lebih lambat dan pengoperasiannya sulit bila dalam kondisi lingkungan yang sangat dingin.

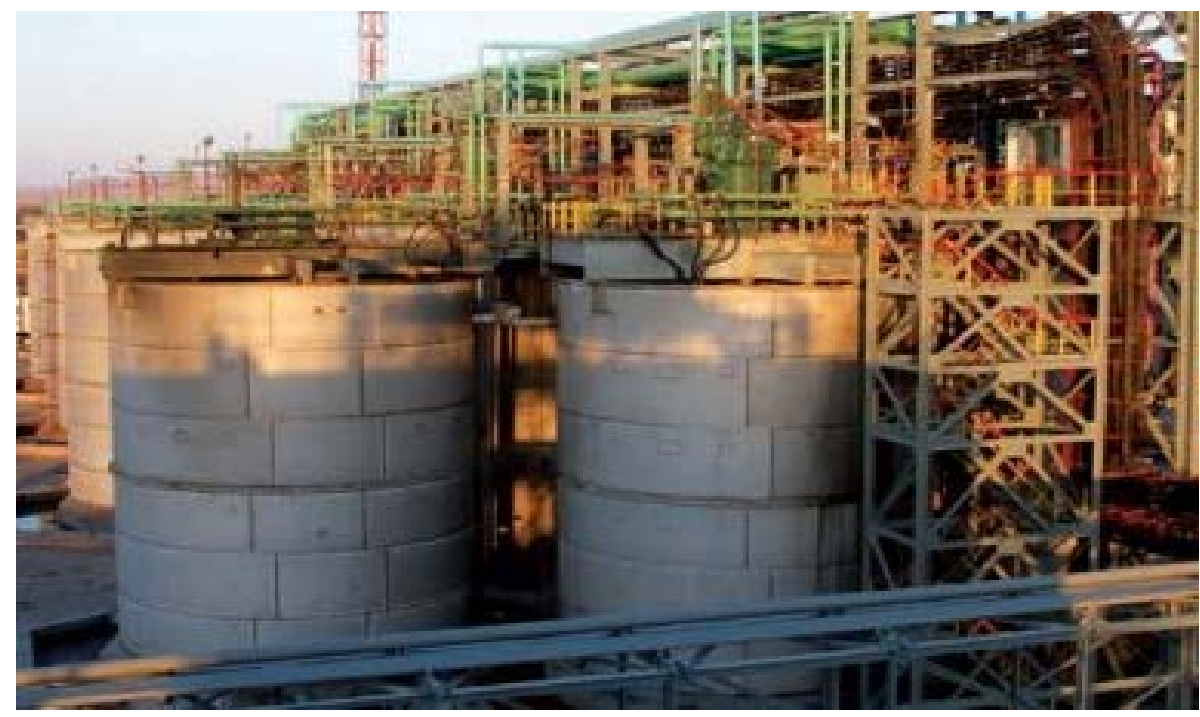

Gambar 4. Pabrik BIOX-biooksidasi konsentrat refraktori emas di Afrika Selatan (Matrix, 2014)

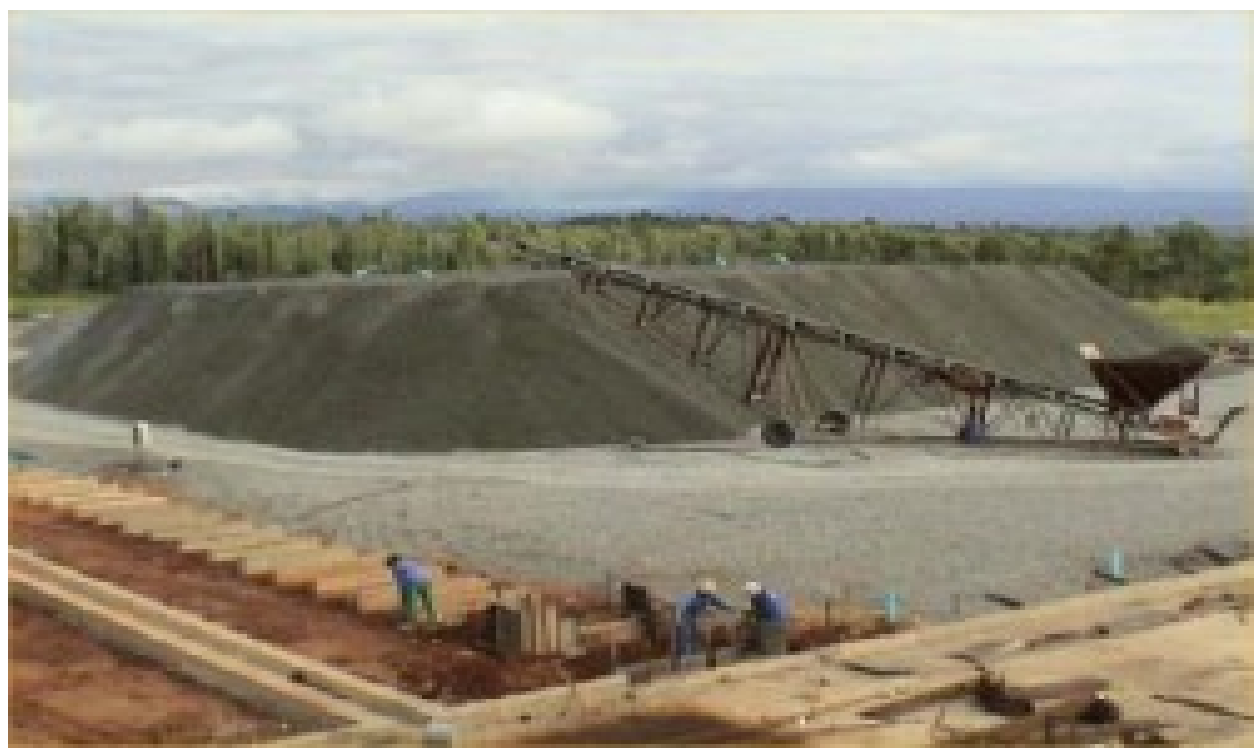

Gambar 5. Biooksidasi secara pelindian onggok (Sumber: Caldwell, 2017) 
Pabrik Yantai di Cina mengolah konsentrat emas refraktori arsenik. Hasil riset awal menunjukkan bahwa perolehan emas untuk konsentrat itu bila tanpa prapengolahan hanya $10 \%$, sedangkan dengan pelindian biooksidasi mengasilkan perolehan emas 91\%. Gambar 6 menampilkan laju alir proses biooksidasi di pabrik Yantai (Songrong $d k k ., 2002$ ).

Konsentrat emas refraktori arsenik yang telah menjalani proses biooksidasi selanjutnya diolah dengan proses Carbon In Pulp (CIP). Dalam proses biooksidasi, konsentrat diumpankan ke sirkuit penggerusan. Limpahan hidrosiklon dipompakan ke tangki pengental berdiameter $12 \mathrm{~m}$. Limpah bawah dari tangki pengental dipindahkan dahulu ke tangki pengkondisi, selanjutnya dipindahkan ke tangki biooksidasi. Setelah proses biooksidasi selesai, sluri dicuci dalam tangki pengental berdiameter $12 \mathrm{~m}$ dan 2 saringan. Limpahan atas mengalir ke dalam sistem netralisasi, dan kue lumpur (filter cake) diumpankan ke dalam proses CIP setelah melewati 2 tahap penyaringan bertekanan dan pencucian. Pabrik biooksidasi ini telah berjalan lancar dengan kapasitas lebih dari 60 ton per hari dan perolehan emasnya mencapai 96\%. Pabrik ini memerlukan investasi rendah dan biaya operasi yang kompetitif untuk setiap ton konsentrat yang diolah.

Adapun pabrik biooksidasi lainnya di Cina, Laizhou, mempunyai kapasitas pengolahan 100 ton per hari. Perbedaannya dengan pabrik Yantai adalah menggunakan proses CCD (Counter Current Decantation). Ukuran tangki biooksidasinya berdiameter 10m, dirancang oleh perusahaan Australia, dan mulai beroperasi sejak 2001 hingga sekarang.

Konsentrat emas refraktori arsenik

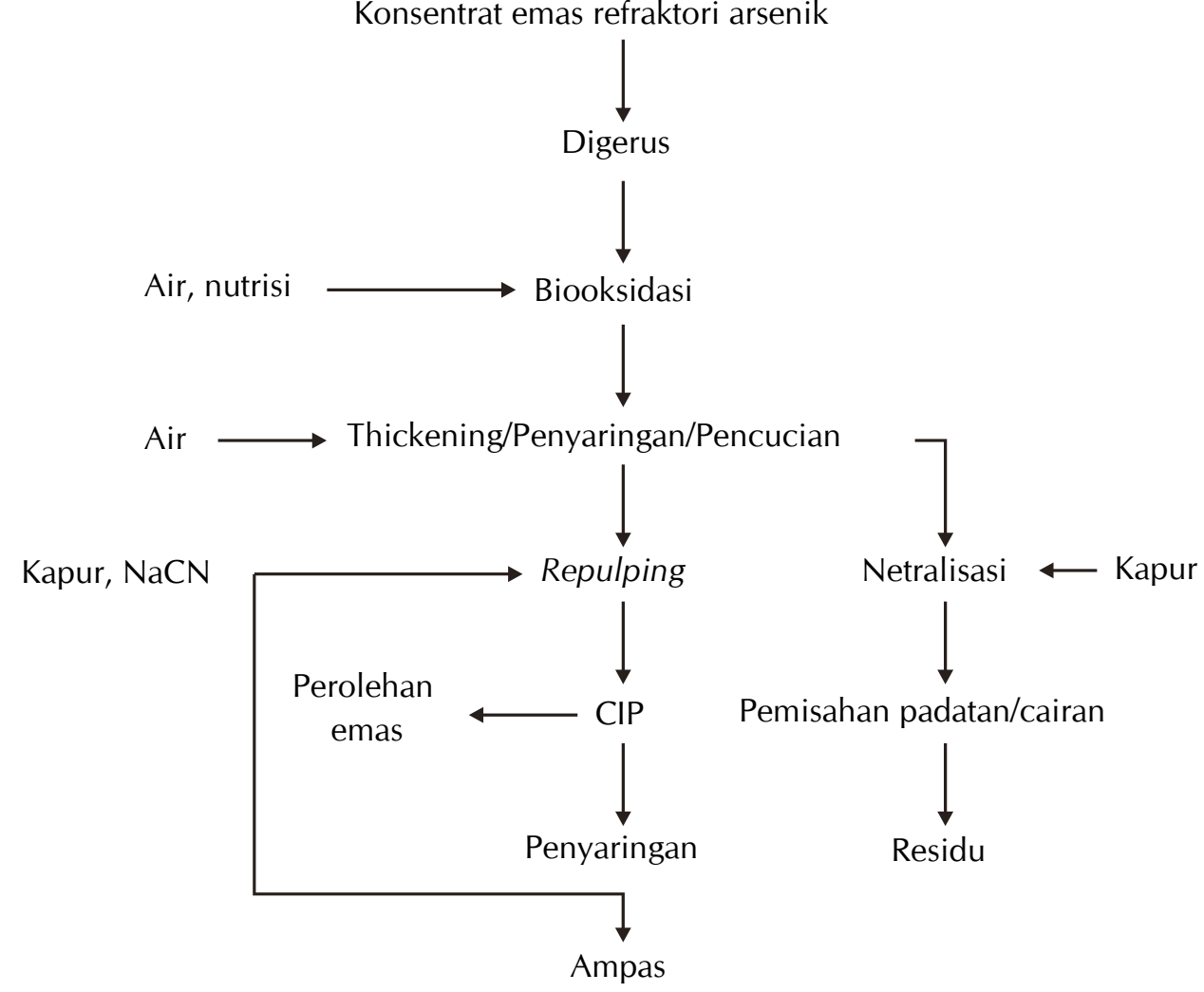

Gambar 6. Bagan alir proses biooksidasi di Pabrik Yantai, Cina (Songrong $d k k ., 2002$ ) 


\section{PERTIMBANGAN EKONOMI}

Pada dasarnya, biaya pendirian pabrik biooksidasi bijih emas refraktori terdiri dari biaya kapital yang berhubungan dengan biaya konstruksi dan biaya operasi yang berkaitan dengan biaya peralatan proses dan reagen serta servis. Biaya kapital dan biaya operasi ini bisa berbeda-beda dari satu negara dengan negara lainnya karena bobot ekonomi dari setiap unsur biaya juga berbeda di setiap negara. Oleh karena itu, studi kelayakan yang akurat dan realistis adalah sangat penting dalam mempertimbangkan penerapan teknologi biooksidasi ini.

Bruynesteyn, Hackl dan Wright (1986) telah mempublikasikan perbandingan yang komprehensif dari biaya kapital dan biaya operasi untuk proses pemanggangan, oksidasi dengan tekanan tinggi dan biooksidasi pirit/arsenopirit di Northern Ontario, Kanada. Datanya ditunjukkan dalam Tabel 2 yang merujuk pada laju proses 100 ton pirit/arsenopirit per hari.

Studi lain mengenai biaya kapital dan biaya operasi untuk 1000 ton/hari operasi pabrik dengan umpan arsenopirit di Congress Mine di Nevada telah dipublikasi pula oleh Hackl, Wright dan Gormely (1989) yang dapat dilihat pada Tabel 3.

Data yang tercantum dalam Tabel 2 dan Tabel 3 memberikan perbandingan yang sangat bermanfaat karena memberikan informasi mengenai nilai dolar yang sebenarnya, dan karena inflasi nilai dolar relatif kecil. Informasi ini dapat diadaptasi kepada situasi di tempat lain untuk mendapatkan perkiraan besarnya biaya yang dibutuhkan untuk proses yang serupa. Studi-studi itu berguna karena memperlihatkan data bahwa alternatif proses itu bisa bervariasi bergantung kepada skala produksi. Variasi tersebut harus dipertimbangkan dalam melakukan studi kelayakan berdasarkan data percobaan untuk penerapannya dalam skala pabrik. Walaupun demikian, secara umum dapat dikatakan bahwa biaya kapital untuk biooksidasi adalah lebih kecil dari proses lain, sedangkan biaya operasi proses biooksidasi ini adalah relatif kompetitif dengan proses lain.

Berikut ini disajikan data lebih baru mengenai biaya kapital pabrik $\mathrm{BIOX}^{\circledR}$ untuk mengolah konsentrat emas refraktori yang dapat dilihat pada Tabel 4 dan 5 (Rawlings dan Johnson, 2007).

Secara umum, biaya kapital yang diperlukan untuk membangun pabrik BIOX ${ }^{\circledR}$ hanya sekitar $50 \%$ dari biaya pendirian pabrik peleburan secara konvensional karena biaya infrastruktur yang jauh lebih hemat. Porsi biaya terbesar adalah untuk reaktor beserta pengaduknya. Biaya reaktor bergantung pada waktu tinggal yang dibutuhkan dan material konstruksi, misal duplex stainless steel yang digunakan memerlukan ketahanan terhadap kadar klorida yang melebihi $500 \mathrm{mg} / \mathrm{L}$ yang berkaitan dengan sifat tahan korosi. Adapun biaya operasionalnya kompetitif dibandingkan dengan pemanggangan.

Tabel 2. Perbandingan biaya berbagai alternatif proses untuk kapasitas 100 ton/hari (Kanada)

\begin{tabular}{cccc}
\hline & Pemanggangan & Oksidasi Tekanan Tinggi & Biooksidasi \\
\hline Biaya kapital US\$ & 4.889 .000 & 7.481 .000 & 3.778 .000 \\
Biaya operasi US\$ & 55,90 & 42,79 & 43,09 \\
\hline
\end{tabular}

Tabel 3. Perbandingan biaya berbagai alternatif proses untuk kapasitas 1000 ton/hari (Nevada, Amerika Serikat)

\begin{tabular}{llll}
\hline & Pemanggangan & Oksidasi Tekanan Tinggi & Biooksidasi \\
\hline Biaya kapital US\$ & 26.170 .000 & 33.880 .000 & 23.140 .000 \\
Biaya operasi US\$ & 19,42 & 20,31 & 18,67 \\
\hline
\end{tabular}


Tabel 4. Biaya kapital pabrik $\mathrm{BIOX}^{\circledR}$

\begin{tabular}{lcc}
\hline \multicolumn{1}{c}{ Deskripsi } & $\%$ & $\%$ Total \\
\hline BIAYA LANGSUNG & & \\
Pengadaan peralatan mekanik & 100 & 38,2 \\
Instalasi peralatan mekanik & 20 & 7,6 \\
Preparasi tanah pabrik & 5 & 1,9 \\
Instalasi pondasi dan struktur baja & 8 & 2,9 \\
Instalasi perpipaan & 20 & 7,6 \\
Instalasi bangunan & 22 & 8,6 \\
Instalasi instrumentasi dan listrik & 16 & 6,1 \\
Pengangkutan & 9 & 3,4 \\
\hline Total Biaya Langsung & 200 & 76 \\
\hline BIAYA TIDAK LANGSUNG & 25 & 19,1 \\
Perekayasaan dan manajemen konstruksi & 10 & 4,6 \\
Cadangan biaya (\% dari biaya langsung) & & 24 \\
\hline Total Biaya Tidak Langsung & & 100 \\
\hline Total Biaya Proyek & & \\
\hline
\end{tabular}

Tabel 5. Biaya operasional pabrik $\mathrm{BIOX}^{\circledR}$

\begin{tabular}{lc}
\hline \multicolumn{1}{c}{ Deskripsi } & \% dari Total \\
\hline Reagen & 49 \\
Kontrol pH & 29 \\
Nutrisi & 16 \\
Pengolahan air & 4 \\
Listrik & 27 \\
Tenaga Kerja & 9 \\
Pemeliharaan & 15 \\
\hline Jumlah & 100 \\
\hline
\end{tabular}

Bukti yang cukup jelas mengenai daya kompetitif teknologi biooksidasi dibandingkan dengan teknologi lain dibuktikan untuk pertama kalinya di Fairview Mine, Afrika Selatan, seperti yang dilaporkan oleh van Aswegen (1993). Bijih mineral tambang ini adalah khas bijih sulfida kompleks, terdiri dari pirit $(70 \%)$ dan arsenopirit (30\%) dengan kandungan emas $8 \mathrm{gr} / \mathrm{ton}, 1,3 \%$ sulfur dan $0,5 \%$ arsen trioksida. Hampir semua emasnya bersifat submikroskopik dengan ukuran partikel $<0,2 \mu \mathrm{m}$. Tambang ini telah beroperasi sejak 1912 dan selama 34 tahun emasnya diperoleh dari konsentrat yang diperoleh dari Edward Roaster. Konsentrat arsenopirit/pirit ini bersifat sangat refraktori sehingga hanya 35\% emas yang dapat dilarutkan dengan sianidasi langsung. Pada awal tahun 1987, pabrik biooksidasi dengan kapasitas 12 ton per hari (BIOX) mulai dioperasikan untuk mengolah $40 \%$ konsentrat, yang akhirnya diperluas menjadi mengolah seluruh konsentrat tahun 1991. Pada Mei 1988, pabrik telah sukses beroperasi selama 18 bulan dengan perolehan emas $5 \%$ lebih tinggi daripada dengan roasting. Pabrik dengan skala penuh dimulai Juli 1991 dan Edward Roaster dihentikan pengoperasiannya. Setelah 6 tahun operasi, $\mathrm{BIOX}^{\circledR}$ ini telah dianggap berhasil secara komersial dan dioperasikan oleh petugas yang tidak begitu tinggi keahliannya (unskilled personnels). Hasil ini telah memberikan keuntungan kepada perusahaan dari segi lebih diterima oleh lingkungan, operasi yang lebih sederhana dan biaya kapital yang lebih rendah. Setelah keberhasilan ini, pabrik biooksidasi kemudian diterapkan di Sao Bento Mine, Brazil yang dimulai Desember 1990, di Ashton Mining Harbor Lights mine, Australia mulai Desember 1991, dan di beberapa tambang emas lain di berbagai negara yang terus berlangsung hingga kini. Sukses-sukses tersebut membuktikan bahwa teknologi biooksidasi adalah layak secara teknik dan komersial.

\section{MASALAH DAN TANTANGAN}

Pabrik biooksidasi yang telah berjalan secara komersial bukannya tanpa masalah. Terbentuknya jarosit selama proses biooksidasi yang menyebabkan konsumsi sianida tinggi (Tanaka dkk., 2015; Kandengwa, 2016), waktu proses yang lama dalam hitungan minggu hingga bulan (Zhang, Feng dan Li, 2016) kasuskasus buka-tutupnya pabrik biooksidasi prapengolahan emas Youanmi dan terlambatnya proses prapengolahan biooksidasi pelindian onggok Newmont mencerminkan sensitifnya proses-proses tersebut, terutama terhadap harga emas di pasar dunia. Walaupun berbiaya relatif rendah dan merupakan proses 
biohidrometalurgi yang inovatif, proses biooksidasi memerlukan kapitalisasi yang substansial untuk komersialisasi skala besar. Perusahaan mungkin akan enggan untuk membuat investasi dalam periode waktu ketika harga emas rendah dan akan menundanya sampai kondisi ekonomi lebih menguntungkan.

Walaupun demikian, hampir pasti bahwa penelitian-penelitian yang inovatif akan terus berlanjut untuk aplikasi secara komersial karena bagaimanapun biohidrometalurgi menawarkan beberapa keuntungan dan kelebihan yaitu operasi yang sederhana, biaya kapital dan biaya operasi yang rendah serta waktu konstruksi yang lebih singkat, dibandingkan dengan alternatif-alternatif proses lain yang ditawarkan. Riset yang bersifat inovatif misalnya dengan menaikkan suhu proses biooksidasi menjadi $60-75^{\circ} \mathrm{C}$. Pemanasan terjadi dengan kandungan 2-3\% sulfida-sulfur sebagai pirit. Temperatur yang lebih tinggi tersebut memerlukan pemanfaatan spesies bakteri lebih spesifik, yaitu Sulfobacillus. Sementara itu, kultur bakteri pengoksidasi mineral campuran mesofilik dan termofilik juga mulai digunakan sebagai inokulan sistem pelindian onggok.

Proses inovatif lainnya untuk biooksidasi bijih emas refraktori adalah kombinasi konsep biooksidasi-heapleaching dengan prapengolahan konsentrat flotasi yang dikembangkan oleh Geobiotics, disebut sebagai GEOCOAT. Teknologi ini menawarkan pilihan proses yang lebih murah untuk prapengolahan konsentrat dan bisa digunakan secara bersamaan untuk biooksidasi konsentrat bernilai tinggi dan bijih bernilai rendah.

\section{POTENSI APLIKASI TEKNOLOGI BIOOKSIDASI DI INDONESIA}

Walaupun teknologi biooksidasi telah berkembang cukup pesat dalam 30 tahun terakhir, dan sudah makin banyak industri pengolahan mineral di seluruh dunia yang mengaplikasikan teknologi ini secara komersial, namun teknologi ini tergolong relatif baru di Indonesia. Sebenarnya potensi untuk menerapkan teknologi ini untuk mengolah bijih emas refraktori cukup menjanjikan. Bagi
Indonesia, emas memberi kontribusi devisa yang cukup besar. Indonesia mempunyai cadangan bijih emas refraktori yang terinklusi dalam pirit, arsenopirit, pirohit dan kalkopirit seperti yang terdapat di Pongkor, Kalimantan Timur dan Sulawesi Selatan, bahkan di Cikondang, Jawa Barat sekitar $80 \%$ dari cadangan emas yang ada bersifat refraktori (Fillis, 1988). Sampai saat ini, bijih refraktori emas tersebut tidak diolah. Sementara itu, Barret dkk. (1993) pernah melakukan penelitian biooksidasi dengan mengambil percontoh dari tiga negara, salah satunya Indonesia. Hasil penelitiannya disajikan dalam Gambar 7. Tampak bahwa perolehan emas dengan sianidasi langsung adalah sangat rendah, berkisar 18-48\%. Setelah diberi perlakuan praolahan dengan biooksidasi, perolehan emas meningkat tajam menjadi 98$100 \%$. Penelitian biooksidasi yang dilakukan oleh Handayani (1996, 2012) terhadap bijih emas refraktori asal Kalimantan Timur juga memperkuat hasil tersebut. Pada sianidasi langsung tanpa praolahan dicapai perolehan emas sebesar $38,7 \%$ dan setelah bijih mengalami pelindian bakteri dalam kolom perkolator selama 42 hari, diperoleh peningkatan ekstraksi emas menjadi sebesar $87,1 \%$. Pada penelitian biooksidasi selanjutnya menggunakan kultur bakteri campuran Acidithiobacillus ferrooxsidans dan Acidithiobacillus thiooxidans, perolehan emasnya meningkat menjadi 98\% dengan waktu proses yang lebih singkat selama 28 hari. Data itu memberi masukan yang sangat berharga bagi industri pengolahan bijih emas untuk mengadopsi teknologi biooksidasi secara komersial di Indonesia. Proses ini sudah terbukti kompetitif untuk mengolah bijih emas refraktori karena harga emas yang tinggi saat ini. Penentuan metode biooksidasi yang akan diterapkan, apakah tangki pelindian berpengaduk (agitated tank leaching) atau pelindian onggok mikroba (bioheapleaching) yang paling sesuai untuk jenis bijih mineral refraktori emas Indonesia, harus didasarkan kepada pertimbangan aspek ilmiah dan ekonomi, seperti karakteristik kimia dari mineral, kadar emas yang terkandung dalam bijihnya, beberapa faktor lokal dan hasiluji karakteristik bijih atau konsentrat terhadap proses biooksidasi. Untuk itu diperlukan studi kelayakan yang akurat dan realistis. 


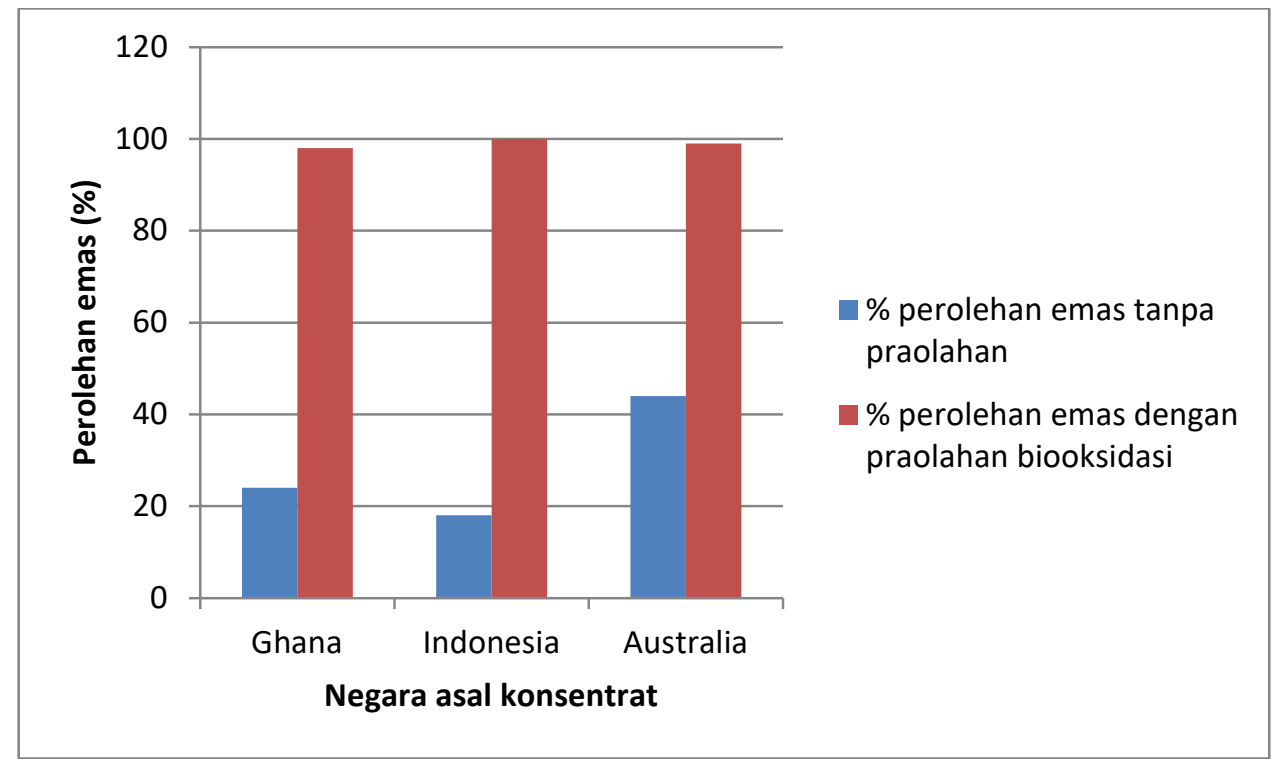

Gambar 7. Peningkatan perolehan emas setelah praolahan dengan biooksidasi

Walaupun teknologi biooksidasi telah terbukti mempunyai keuntungan dari segi ekonomis dan lingkungan, insentif lebih masih diperlukan untuk mendukung perusahaan swasta mengadopsi teknologi ini. Insentif tersebut bisa dalam bentuk keringanan pajak atau bentuk-bentuk pembiayaan lain. Implementasi teknologi biooksidasi juga bisa didorong dengan penekanan regulasi yang lebih ketat untuk mendukung teknologi yang bersifat berkelanjutan (sustainable mining and processing technologies) seperti teknologi biooksidasi.

\section{KESIMPULAN}

Aplikasi bioteknologi dalam pengolahan bijih emas refraktori diyakini merupakan hal yang sangat penting di masa kini dan masa depan karena dengan berlalunya waktu maka bijih emas berkadar tinggi akhirnya akan habis dan tinggalah mineral berkadar rendah dan kompleks yang tidak akan ekonomis lagi bila diolah dengan teknologi pengolahan konvensional yang umum diterapkan saat ini. Teknologi biooksidasi bisa mulai dijajagi agar diterapkan dalam pengolahan bijih emas refraktori yang cadangannya cukup besar di Indonesia untuk meningkatkan perolehan emas yang masih sangat rendah bila diolah dengan proses sianidasi langsung. Oleh karena itu, penelitian maupun penerapannya hendaknya mendapat dukungan yang cukup memadai dari industri pertambangan sebagai sebuah transfer teknologi ke industri. Hal itu untuk mengantisipasi masa depan yang pasti akan kita hadapi. Industri pertambangan umumnya enggan melakukan investasi dalam pengembangan dan aplikasi teknologi baru bila tidak dirasakan segera. Industri pertambangan lebih memfokuskan diri dalam hal mengurangi biaya operasi supaya tetap dapat bertahan. Demikian keadaan yang umum dihadapi oleh industri pertambangan saat ini. Kini di seluruh dunia sudah ada lebih dari 10 negara yang telah menerapkan teknologi biooksidasi untuk mengolah bijih emas refrakori. Indonesia pun sudah seharusnya melakukan hal yang sama agar tidak terus menerus terlambatdan selalu tertinggal dari negara-negara lain.

\section{UCAPAN TERIMA KASIH}

Naskah tulisan ini dapat terwujud atas dukungan dan izin dari Pusat Penelitian dan Pengembangan Teknologi Mineral dan Batubara. Ucapan terima kasih penulis sampaikan kepada Dr. Andang Setiawan dari Institut Teknologi Bandung dan Ir. Wiku Padmonobo dari PT Geoservice atas masukan dan diskusi yang sangat bernilai. 


\section{DAFTAR PUSTAKA}

Aazami, M., Yoozbashizadeh, H., Darban, A. K. and Abdolahi, M. (2013) "Determination of the optimum conditions for recovery of gold from Zarshuran refractory gold sulfide ore," Iranian Journal of Material Science and Engineering, 10(4), pp. 8-17.

Anonymous (2008) Acidithiobacillus ferrooxidans ATCC 53993, Bacmap Genome Atlas. Available at:

http://bacmap.wishartlab.com/organisms/750 (Accessed: July 9, 2017).

Anonymous (2017) This is gold definitions, This is Gold. Available at:

http://www.thisisgold.co.za/facts-andfigures/definitions (Accessed: February 20, 2017).

Bactech (2017) Bioleaching: A game changing technology in the tailing reclamation industry, www.bactechgreen.com. Available at:

http://www.bactechgreen.com/s/Overview.as p (Accessed: June 13, 2017).

Barret, J., Hughes, M. N., Karavaiko and Spencer, P. A. (1993) Metal Extraction by Bacterial Oxidation of Minerals. New York: Ellis Horwood Ltd.

Brierley, C. L. (2010) "Management in actionbiomining: Biomining Beckon," www.miningmagazine.com, pp. 324-328.

Brierley, J. A. (2008) "A perspective on developments in biohydrometallurgy," Hydrometallurgy, 94(1-4), pp. 2-7. doi: 10.1016/j.hydromet.2008.05.014.

Bruynesteyn, A., Hackl, R. P. and Wright, F. (1986) "The biotankleach process," in Fivaz, C. E. (ed.) Gold 100 , Proceedings of the International Conference of Gold, Volume 2. Johannesburg: South African Institute of Mining and Metallurgy (SAIMM), pp. 353365.

Caldwell, J. (2017) Biotechnology, TechnoMine Mining Technology. Available at: http://technology.infomine.com/reviews/biote chnology/welcome.asp?view = full (Accessed: February 20, 2017).

Engineers, D. M. (2017) The basic processes of gold recovery, Denver Mineral Engineers, Inc. Available at: http://www.denvermineral.com/gold-miningprocess-development/ (Accessed: July 10, 2017).

Fillis, P. N. (1988) Independent geologist report on Cikondang project.

Flatman, S., Battersby, M., Imhof, R., Battersby, R. M. and Ibrayev, S. (2014) The Leachnox refractory gold process, the testing, design, installation and commissioning of a large scale plant at the Vasgold gold mine, Kazakhstan.

Goodbody, A. (2012) "Recovering refractory resources," Mining Magazine. Available at: http://www.miningmagazine.com/manageme $\mathrm{nt} /$ general-management/recovering-refractoryresources/.

Hackl, R. P., Wright, F. R. and Gormely, L. S. (1989) "Bioleaching of refractory gold ores out of the lab into the plant," in 7th International Symposium on Biohydrometallurgy. Jackson Hole, Wyoming.

Handayani, S. (1996) "Biooksidasi bijih emas refraktori Kalimantan Timur dengan Thiobacillus ferrooxidans," in Prosiding Seminar Temu Peneliti Muda Departemen Pertambangan dan Energi: Peran Lembaga Litbang dalam Menunjang Industri Pertambangan di Indonesia. Bandung: Puslitbang tekMIRA.

Handayani, S. (2012) "Pengaruh penambahan ion $\mathrm{Ag} 2+$ terhadap laju biooksidasi mineral sulfida," Jurnal Teknologi Mineral dan Batubara, 8(2), pp. 88-96.

Kandengwa, M. (2016) Characterization of jarosite formed during biooxidation of refractory gold ores and its effect on cyanide consumption during gold leaching. Kandengwa, Michael.

Karthikeyan, O. P., Rajasekar, A. and Balasubramanian, R. (2015) "Bio-Oxidation and Biocyanidation of Refractory Mineral Ores for Gold Extraction: A Review," Critical Reviews in Environmental Science and Technology, 45(15), pp. 1611-1643. doi: 10.1080/10643389.2014.966423.

Leng, F., Sun, S., Wang, Y., Jing, Y., Wei, Q. and $\mathrm{Li}, \mathrm{H}$. (2016) "Arsenic bioleaching in medical realgar ore and arsenicbearing refractory gold ore by combination of Acidithiobacillus ferrooxidans and Acidithiobacillus thiooxidans," Tropical Journal of Pharmaceutical Research, 15(5), p. 1031. doi: 10.4314/tjpr.v15i5.19. 
Martínez-Bussenius, C., Navarro, C. A. and Jerez, C. A. (2017) "Microbial copper resistance: importance in biohydrometallurgy," Microbial Biotechnology, 10(2), pp. 279295. doi: 10.1111/1751-7915.12450.

Matrix (2014) Outotec completes acquisition of Biox technology, International Mining (IM). Available at:

http://im-mining.com/2015/11/24/outoteccompletes-acquisition-of-biox-technology/ (Accessed: February 20, 2017).

Meybodi, S. M., Heydari, M. A., Nejad, I. G., Mobini, M. and Salehi, M. (2013) "Facilitate of gold extracting from Moutech refractory gold ore using indigenous bacteria," International Journal of Bio-Inorganic Hybrid Nanomaterials, 2(2), pp. 365-371. Available at: http://ijbihn.iauvaramin.ac.ir/article_4032.html.

van Niekerk, J., van den Heuvel, C. and van Buuren, C. (2014) Complete refractory gold solution.

Rawlings, D. E. and Johnson, D. B. (2007) "The microbiology of biomining: development and optimization of mineral-oxidizing microbial consortia," Microbiology, 153(2), pp. 315324. doi: 10.1099/mic.0.2006/001206-0.

Roberto, F. F. (2017) "Commercial heap biooxidation of refractory gold ores Revisiting Newmont's successful deployment at Carlin," Minerals Engineering, 106, pp. 26. doi: 10.1016/j.mineng.2016.09.017.

Rohwerder, T., Gehrke, T., Kinzler, K. and Sand, W. (2003) "Bioleaching review part A: Progress in bioleaching: fundamentals and mechanisms of bacterial metal sulfide oxidation," Applied Microbiology and Biotechnology, 63(3), pp. 239-248. doi: 10.1007/s00253-003-1448-7.

Schippers, A., Hedrich, S., Vasters, J., Drobe, M., Sand, W. and Willscher, S. (2013) "Biomining: Metal Recovery from Ores with Microorganisms," in Schippers, A. Glombitza, F., and Sand, W. (eds.) Geobiotechnology I (Metal-related Issues). Advances i. Berlin Heidelberg: Springer Berlin Heidelberg, pp. 1-47. doi: 10.1007/10_2013_216.

Shumilova, L. V. (2016) "Mineral and technogenic raw materials processing and concentration," Mining Science and Technology, 1, pp. 3-13.
Available

at: http://mst.misis.ru/jour/article/download/12/31.

Songrong, Y., Jiyuan, X., Guanzhou, Q. and Yuehua, H. (2002) "Research and application of bioleaching and biooxidation technologies in China," Minerals Engineering, 15(5), pp. 361-363. doi: 10.1016/S08926875(02)00019-5.

Tanaka, M., Yamaji, Y., Fukano, Y., Shimada, K., Ishibashi, J.-I., Hirajima, T., Sasaki, K., Sawada, M. and Okibe, N. (2015) "Biooxidation of gold-, silver, and antimonybearing highly refractory polymetallic sulfide concentrates, and its comparison with abiotic pretreatment techniques," Geomicrobiology Journal, 32(6), pp. 538-548. doi: 10.1080/01490451.2014.981645.

Taylor, A. (2013) "Developments in the processing of refractory and complex gold ores," in AusIMM Bendigo Technical Meeting. Melbourne, Australia: ALTA Metallurgical Services Publications, pp. 1-15.

Van Aswegen, P. C. (1993) "Bio-oxidation of refractory gold ores," in Biomine '93 Conference Proceedings; XV. Adelaide, Australia.

Wang, G., Xie, J., Li, S., Guo, Y., Pan, Y., Wu, H. and Liu, X. (2016) "Two-step oxidation of refractory gold concentrates with different microbial communities," Journal of Microbiology and Biotechnology, 26(11), pp. 1871-1880. doi: 10.4014/jmb.1511.11031.

Watling, H. (2016) "Microbiological Advances in Biohydrometallurgy," Minerals, 6(2), p. 49. doi: 10.3390/min6020049.

Winarko, R., Mubarok, M. Z., Rizki, I. N. and Chaerun, S. K. (2015) "Biooxidation of carbonaceous refractory gold ores by an ironsulfur-oxidizing mixotrophic bacterium at neutral $\mathrm{pH}, "$ Advanced Materials Research, 1130, pp. 440-444. doi: 10.4028/www.scientific.net/AMR.1130.440.

Zhang, X., Feng, Y. and Li, H. (2016) "Enhancement of bio-oxidation of refractory arsenopyritic gold ore by adding pyrolusite in bioleaching system," Transactions of Nonferrous Metals Society of China, 26(9), pp. 2479-2484. doi: 10.1016/S10036326(16)64339-X. 
